\title{
GEOMORPHOLOGICAL ANALYSIS FOR THE IDENTIFICATION OF SMALL VOLCANIC ISLANDS IN NORTH MALUKU, INDONESIA
}

\section{Bachtiar W. Mutaqin', Warsini Handayani ${ }^{2}$, Fredi Satya Candra Rosaji ${ }^{3}$, Desy Wahyuningtyas ${ }^{1}$, Muh Aris Marfai ${ }^{1,4}$}

${ }^{1}$ Coastal and Watershed Research Group, Fakultas Geografi, Universitas Gadjah Mada, Jl, Kaliurang, Sekip Utara, Bulaksumur, Sleman, Yogyakarta, 55281, Yogyakarta 2Remote Sensing and Geographic Information System, Sekolah Vokasi, Universitas Gadjah Mada

Jl, Kaliurang, Sekip Utara, Bulaksumur, Sleman, Yogyakarta, 55281, Yogyakarta

${ }^{3}$ Mitra Geotama Indonesia, Sinduadi, Mlati 55284 Yogyakarta

Jl. Kalimantan, Sinduadi, Sleman, Yogyakarta, 55284, Indonesia 4Badan Informasi Geospasial

Jl. Raya Bogor km 46, Nanggewer Mekar, Cibinong, Bogor, 16912, Indonesia e-mail: mutaqin@ugm.ac.id

Received: 09 December 2020, Repaired: 22 May 2021, Approved: 03 June 2021

\begin{abstract}
Abstrak
Indonesia yang berada dalam lingkaran cincin api Pasifik mempunyai setidaknya 100 gunungapi aktif yang tersebar diantara lebih dari 17.000 pulau. Beberapa gunungapi aktif berada di pulau kecil sehingga membutuhkan upaya yang lebih besar kaitannya dengan manajemen bencana, khususnya yang terkait dengan kegunungapian. Namun demikian, penelitian tentang identifikasi pulau vulkanik kecil belum banyak dilakukan di Indonesia. Penelitian ini mencoba untuk mengisi kekosongan tersebut dengan menggunakan pendekatan aspek geomorfologi, yang terdiri dari morfologi, morfogenesa, morfokronologi, dan morfoaransemen, untuk melakukan identifikasi pulau vulkanik kecil di Provinsi Maluku Utara. Telaah pustaka dan pengumpulan data spasial dilakukan untuk menentukan parameter-parameter yang digunakan dalam identifikasi pulau vulkanik kecil. Berdasarkan hasil telaah pustaka, penelitian ini menggunakan 5 (lima) parameter, yaitu luas pulau, tipe material, lokasi/morfoaransemen, tipe aliran sungai, dan fitur bentuklahan yang meliputi keterdapatan bentuklahan asal proses vulkanik (morfokronologi), kelerengan, dan morfologi. Berdasarkan analisis spasial dengan menggunakan 5 parameter tersebut, diperoleh informasi bahwa di Maluku Utara terdapat setidaknya 6 dari 17 pulau yang memenuhi kriteria untuk disebut sebagai pulau vulkanik kecil. Data pulau vulkanik kecil beserta karakteristiknya menjadi informasi penting untuk mengedukasi masyarakat dan meningkatkan kesiapsiagaan.
\end{abstract}

Kata kunci: morfologi, morfogenesa, morfokronologi, morfoaransemen, pulau vulkanik kecil.

\begin{abstract}
Indonesia, which is located in the Pacific Ring of Fire, has at least 100 active volcanoes that are spread among more than 17,000 islands. Several active volcanoes are located on small islands, so they require a greater effort in relation to disaster management, especially those related to volcano activities. However, research on the identification of small volcanic islands has not been widely carried out in Indonesia. This study tries to fill the gap using a geomorphological aspect approach, which consists of morphology, morphogenesis, morphochronology, and morphoaransement, to identify small volcanic islands in North Maluku Province. Literature review and spatial data collection were carried out to determine the parameters used in the identification of small volcanic islands. Based on the literature review, this study uses 5 (five) parameters, namely the
\end{abstract}


island area, the type of material, the location / morphoaransement, the pattern of river flow, and the features of the landforms which include the presence of volcanic landform (morphochronology), slope, and morphology. Based on the spatial analysis using these 5 parameters, information is obtained that there are at least 6 of the 17 islands that meet the criteria to be called small volcanic islands in North Maluku. Data on small volcanic islands and their characteristics are important information to educate the public and improve preparedness.

Keywords: morphology, morphogenesis, morphochronology, morphoaransement, small volcanic islands.

\section{INTRODUCTION}

Indonesia has more than 100 active volcanoes spread both on large islands (Sumatra, Java, Sulawesi) and on small islands (Maluku, East Nusa Tenggara, Anak Krakatau, Lombok) (Mutaqin, Lavigne, Hadmoko, \& Malawani, 2019a; Mutaqin et al., 2019b) (Figure 1). Based on its location, disaster management of volcanic eruptions on small islands requires greater effort than the management of volcanic eruptions on larger islands, such as Merapi and Kelud
Volcano in Java Island (Thouret, Abdurachman, Bourdier, \& Bronto, 1998; Lavigne, Thouret, Voight, Suwa, \& Sumaryono, 2000; Thouret, Lube, Liew, Cronin, \& Surono, 2010; Mei et al., 2013; de Belizal et al., 2013; Hadmoko et al., 2018), Anak Krakatau Volcano in Sumatra Island (Mutaqin et al., 2019a), and Samalas (Barujari) Volcano in Lombok Island (Mutaqin et al., 2019b; Mutaqin \& Lavigne, 2019).

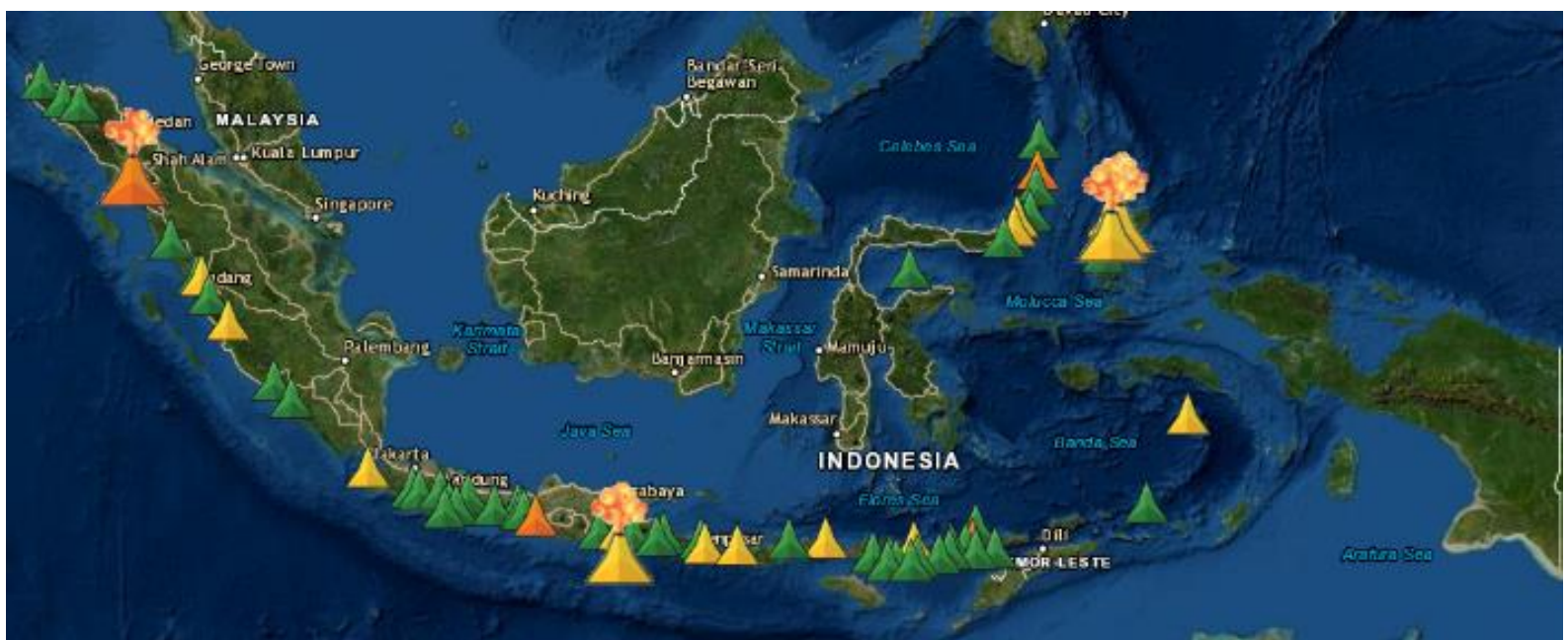

Figure 1. The distribution of volcanoes in Indonesia on the website of MAGMA Indonesia (https:/ / magma.vsi.esdm.go.id/) with information on the status of each volcano, namely: Level I/Normal (Green), Level II/ Advisory (Yellow), Level III/Watch (Orange), and Level IV/Warning (Red) (Courtesy: MAGMA Indonesia, 2020)

This situation is caused by several factors and limitations, such as limited space or place, limited natural resources, locations that are difficult to reach (insularity), vulnerability to natural disasters, vulnerable to ecosystem damage, difficulties in transportation and communication, limited internet networks, limited market, limited supply of clean water, and high dependence on imports (Wilkinson, Lovell, Carby, Barclay, \& Robertson, 2016). Due to these limitations, small islands are more at risk in the event of a catastrophic volcanic eruption (Mutaqin et al., 2019a; Mutaqin et al., 2019b; Hidayat, 
Marfai, \& Hadmoko, 2019; Hidayat, Marfai, \& Hadmoko, 2020).

Research on small volcanic islands has not been widely carried out in Indonesia. Several volcanic studies on small islands were carried out within the framework of eruption disaster management, including evacuation modeling on Ternate Island in North Maluku (Syiko, Ayu, \& Yudono, 2013), agroforestry and disaster risk reduction on small volcanic islands (Rampengan et al., 2016), and mapping of small volcanic islands based on the history of eruptions during the Holocene era (Hidayat et al., 2019).
Hidayat et al. (2019) has mapped small volcanic islands in Indonesia, but the parameters used in their research are still very limited, namely the size of the island, the location of the volcano, and the history of volcanic eruptions. This study uses a geomorphological approach, which consists of morphology, morphogenesis, morphochronology, and morphoarrangement, to identify small volcanic islands in North Maluku Province. North Maluku Province was used as the research location because North Maluku is a double subduction area of the Sangihe arc and Halmahera arc, with very active tectonic activity (Figure 2).

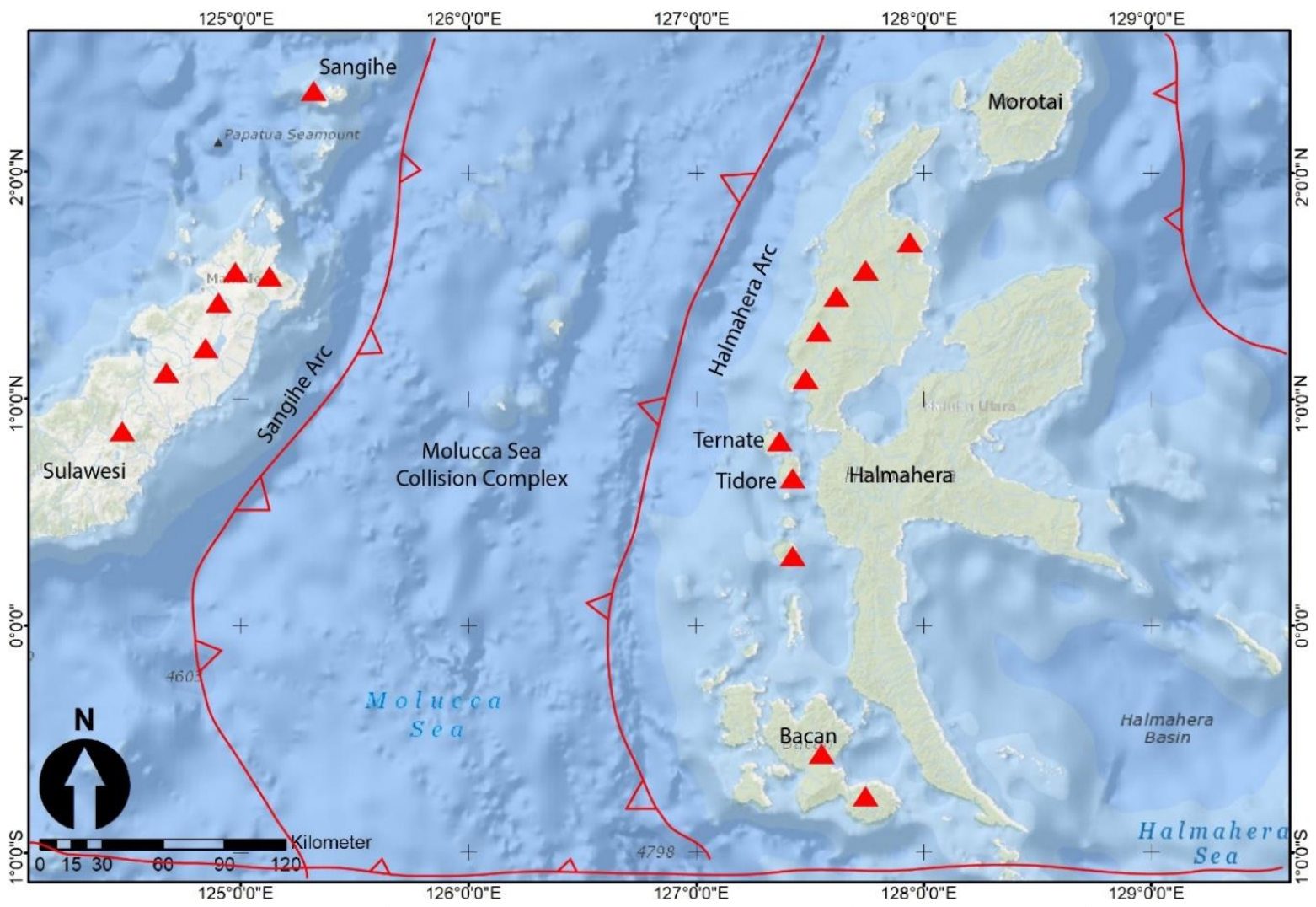

Figure 2. Geodynamics of North Maluku with a double subduction zone of the Sangihe arc and the Halmahera arc, with very active tectonic activity (Hall \& Wilson, 2000)

The geomorphological approach for identifying and mapping small volcanic islands is the first step in disaster management on small volcanic islands. Data on small volcanic islands and their characteristics are important information for increasing public awareness and preparedness.

\section{METHODOLOGY}

This research begins with conducting a literature review and data collection to determine the parameters that will be used in the identification of small volcanic islands. Processes and volcanic landforms are relatively difficult to study terrestrially because of their long formation 


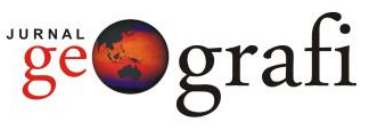

time in geologic time scale, large scale, remote and difficult to reach locations, and dangerous eruptive activities. Observations using geospatial data by paying attention to geomorphological aspects are one of the effective and efficient methods for documenting and observing the processes and formations of volcanic landforms (Napieralski, Barr, Kamp, \& Kervyn, 2013).

Data sources used in this research including the Digital Elevation Model of Indonesia (DEMNAS) data from the Indonesian Geospatial Information Agency which can be obtained freely via the link http://tides.big.go.id/DEMNAS/, Worldview satellite images recorded in November 2014, SPOT 7 images, Pleiades images recorded in August 2019, geological maps from the Indonesian Geological Agency, as well as various scientific articles discussing volcanoes, especially those on small islands.
Before being used for processing, images are pre-processed for visual quality improvement and geometry correction, including spatial sharpening (pan-sharp), orthorectification with DEMNAS data, and mosaics.

The definition of an island refers to Article 121 in the United Nations Convention on the Law of the Sea (UNCLOS) 1982, i.e., an island is an area of land that is naturally formed, surrounded by water, and remains visible or above sea level during high tide conditions. The definition of the small island used in this study refers to the Indonesian Law no. 27 of 2007 concerning the Management of Coastal Areas and Small Islands in Article 1, the third point, i.e., that small islands are islands that have an area of less than or equal to $2,000 \mathrm{~km}^{2}$. The systematic review is briefly presented in Figure 3.

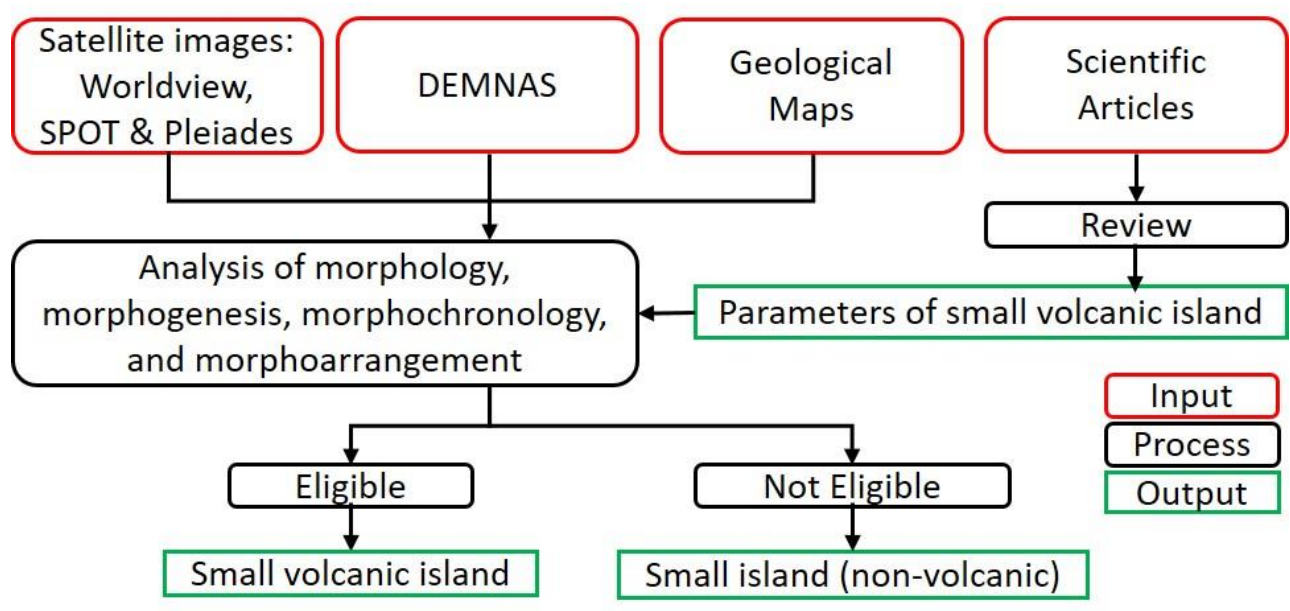

Figure 3. Systematic of geomorphological analysis for identification of small volcanic islands in North Maluku

\section{RESULTS AND DISCUSSIONS}

Based on literature reviews, this study uses 5 (five) parameters, namely island area, material type, location/ morphoarrangement, river flow patterns, and landform features which include the presence of landforms from volcanic processes (morphochronology), slopes, and morphology. Those parameters in more detail are presented in Table 1.

The characteristics of small volcanic islands presented in Table 1 serve as the basis for the identification method, namely by extracting physical parameters from DEM spatial data and remote sensing images. Based on the characteristics of small volcanic islands in Table 1, several physical parameters that can be detected through DEM spatial data and remote sensing are area, relief, slope, profile type, contour pattern, and river flow pattern (Thouret, 1999; Kervyn et al., 2007; Napieralski et al., 2013; Santamarta et al., 2014; Velmurugan, 2018; Chan et al., 2019; Coello-Bravo et al., 2020; Stokes and Gomes, 2020). 
Table 1. Parameters of the small volcanic island

\begin{tabular}{ccl}
\hline No & Parameter & \multicolumn{1}{c}{ Information } \\
\hline 1 & Area & $\begin{array}{l}\text { Smaller than or equal to } 2,000 \mathrm{~km}^{2} \text { (two thousand square } \\
\text { kilometers) along with the unity of the ecosystem. }\end{array}$ \\
2 & Material $\begin{array}{l}\text { The result of volcanic processes (pyroclastic material, lava, debris } \\
\text { avalanche) or sub-aerial deposition. }\end{array}$
\end{tabular}

3 Location Separate from the main island/hotspot and close to the subduction zone.

4 River Usually seasonal streams, the river flow pattern is centrifugal radial.

a) There are active or inactive cones/craters/calderas/domes/ maars; b) In one island there may be more than one cone/crater/

$5 \quad$ Fitur caldera/domes, which are included in one volcanic complex or different complexes; c) The island has a predominantly hilly and mountainous morphology; and d) The island has a steep slope $>25 \%$.

Sources concerning the Management of Coastal Areas and Small Islands

Thouret, 1999; Kervyn, Kervyn, Goossens, Rowland, \& Ernst, 2007; Napieralski et al., 2013; Chan et al., 2019; Coello-Bravo, Márquez, Herrera, Huertas, \& Ancochea, 2020.

Santamarta, Lario-Bascones,

Rodríguez-Martín,

Hernández-Gutiérrez, \&

Poncela, 2014; Stokes \&

Gomes, 2020

Santamarta et al., 2014

Thouret, 1999; Kervyn et al., 2007; Napieralski et al., 2013; Velmurugan, 2018; Chan et al., 2019.

Source: Research analysis, 2020

The first parameter used in determining a small island is that the island has an area of $\leq 2,000 \mathrm{~km}^{2}$. This area can be found automatically by calculating the area geometry in the Geographical Information System software. Previously, DEMNAS data in the form of raster data was carried out by land and sea segregation $(<0$ meters categorized as the sea), then converted into vector data so that area calculations could be carried out. After obtaining the categories of small islands and main islands, buffering is still carried out with a distance of $2 \mathrm{~km}$ to eliminate islands that are still associated with large islands, so that vector data for small islands and main islands are obtained (Figure 4).

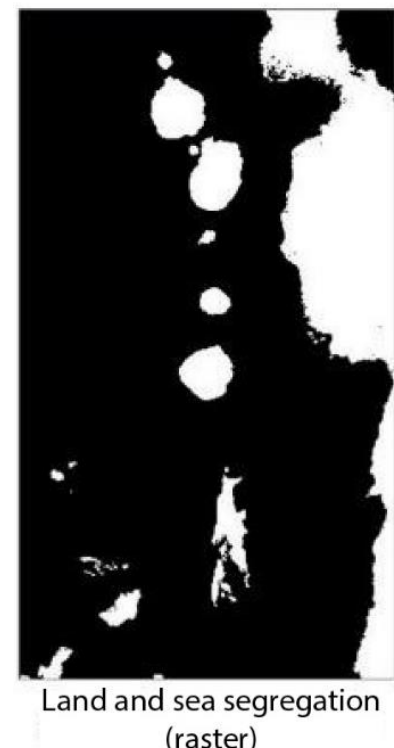

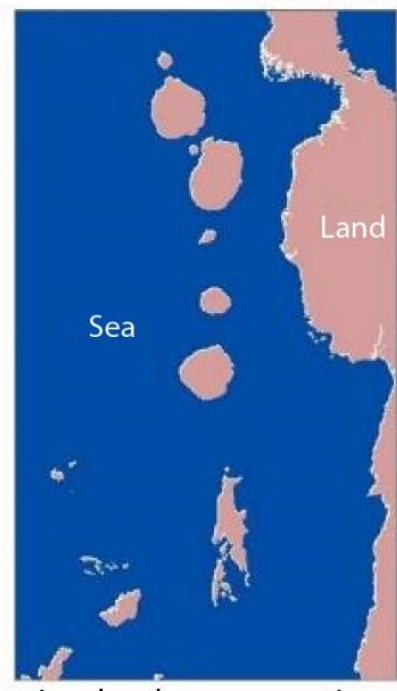

Land and sea segregation (vector)

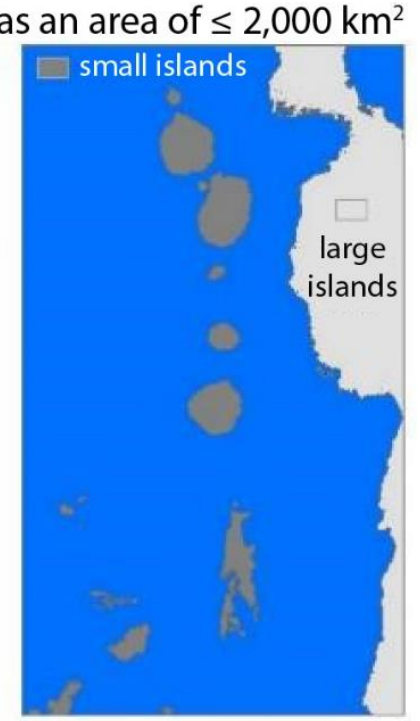

Segregation of large and small islands

Figure 4. An example of the process of separating large and small islands in North Maluku based on the Indonesian Law no. 27 of 2007 


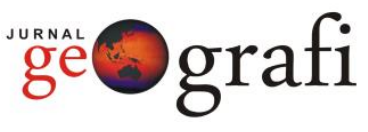

Material and location information is obtained from a combination of geological maps and remote sensing data. Gamalama Volcano is an example of a volcano located on a small island, namely Ternate Island (Hidayat et al., 2019). In terms of potential volcanic hazards, data from the Indonesian Ministry of Energy and Mineral Resources states that Gamalama Volcano has a history of eruptions from 1538 to 2014. The eruption of Gamalama Volcano in 1538 was the first recorded eruption, while a major eruption occurred in 1775 (Hidayat et al., 2020). The eruption in 1775 resulted in the formation of a maar in the northwest of the island of Ternate.

Gogarten (1918) stated that the formation of a hole that was recently known as Tolire Jaha (local terms for a large hole), was preceded by a large-scale tectonic earthquake. The eruption in 1775 was the biggest Gamalama Volcano disaster which produced the maar craters of Tolire Jaha and Tolire Kecil (local terms for a small hole) with 141 people buried with the disappearance of Soela Takomi Village.

At the end of 2014, Gamalama Volcano erupted again with a height of volcanic ash reaching $1.7 \mathrm{~km}$ from the top of the mountain. The impact of the 2014 eruption included ash rain in Ternate City and the closure of Sultan Babullah Airport activities for up to three days. The results of the separation of large and small islands in North Maluku were analyzed for morphoarrangement with subduction zones and are presented in Figure 5.

Subduction zones have a relationship with the emergence of volcanoes in an area. Therefore, it is necessary to check the position of the study area with the presence of the subduction zone. The position of the small islands studied in this study is associated with the existence of a subduction zone, especially Ternate Island and its surroundings which are located east of the subduction zone of the Maluku Sea.

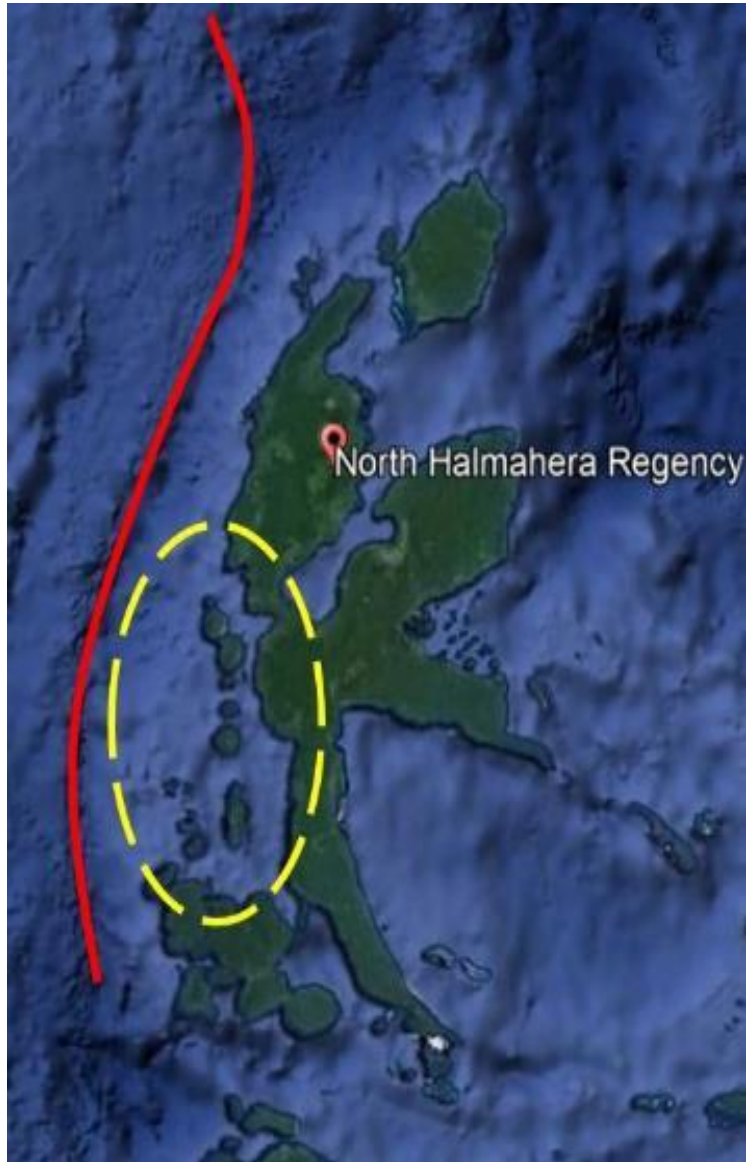

Figure 5. Location of small islands in research location (yellow circles) associated with subduction zones (red lines) according to one of the characteristics of small volcanic islands (Santamarta et al., 2014; Stokes and Gomes, 2020)

Relief, slope percentage, and profile type are used to determine the specific characteristics of the volcanic landscape, namely steep and mountainous slopes (Thouret, 1999; Kervyn et al., 2007; Napieralski et al., 2013; Velmurugan, 2018; Chan et al., 2019) (Figures 6-7). Elevations can also be extracted from contours with repeating rounded patterns, dense, and large height values on the represented contour lines (Figure 8). In addition, radial centrifugal river flow patterns can also be extracted automatically from DEMNAS data (Santamarta et al., 2014) (Figure 9). 


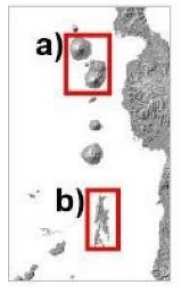

a)

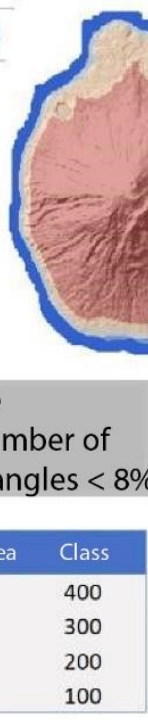

Slope percentage represents the number of areas with slope angles $<8 \%$

\begin{tabular}{|rc|}
\hline Percentage of slope area & Class \\
\hline $0-20 \%$ & 400 \\
$21-50 \%$ & 300 \\
$51-80 \%$ & 200 \\
$81-100 \%$ & 100 \\
\hline
\end{tabular}



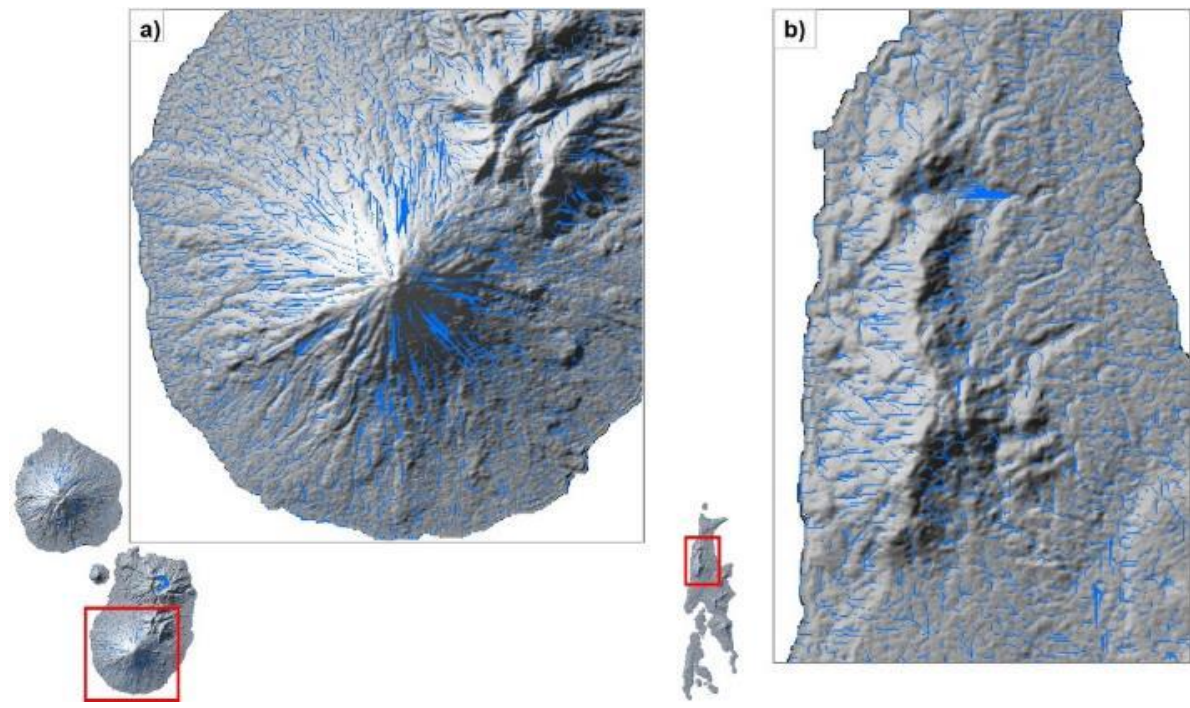

Figure 9. Examples of different river flow patterns on Ternate, Maitara, and Tidore Islands (a) and Kayoa Island (b)

Based on spatial analysis using the parameters of island area, material type, location/morphoarrangement, type of river flow patterns, and landform features which include the presence of landforms from volcanic processes (morphochronology), slopes, and morphology, information was obtained that in North Maluku there are at least 6 of 17 islands that meet the criteria to be referred to as small volcanic islands, namely Hiri, Ternate, Maitara, Tidore, Moti, and Makian islands. More details are presented in Table 2.

Table 2. Small volcanic islands in North Maluku based on geomorphological aspects

\begin{tabular}{|c|c|c|c|c|c|c|c|c|c|c|}
\hline \multirow{3}{*}{$\mathrm{Nu}$} & \multirow{3}{*}{ Name } & \multicolumn{8}{|c|}{ Characteristics } & \multirow{3}{*}{$\begin{array}{l}\text { Conclu- } \\
\text { sion }\end{array}$} \\
\hline & & \multirow{2}{*}{$\begin{array}{l}\text { Area } \\
\leq 2,000 \\
\mathrm{~km}^{2}\end{array}$} & \multirow{2}{*}{$\begin{array}{l}\text { Near } \\
\text { subduc } \\
\text { tion } \\
\text { zone }\end{array}$} & \multirow{2}{*}{$\begin{array}{l}\text { Radial } \\
\text { river } \\
\text { flow } \\
\text { pattern }\end{array}$} & \multirow[t]{2}{*}{ Material } & \multirow{2}{*}{$\begin{array}{l}\text { There are active } \\
\text { \& inactive cones } \\
\text { /craters/calde- } \\
\text { ras/domes/ } \\
\text { maars }\end{array}$} & \multirow{2}{*}{$\begin{array}{l}\text { Steep } \\
\text { slope } \\
(>25 \%)\end{array}$} & \multicolumn{2}{|c|}{$\begin{array}{l}\text { Hilly and } \\
\text { mountainous } \\
\text { morphology }\end{array}$} & \\
\hline & & & & & & & & $\%$ & $\begin{array}{c}\text { Avail } \\
\text { able }\end{array}$ & \\
\hline 1 & Hiri & Yes & Yes & Yes & $\begin{array}{l}\text { Holocene volcanic } \\
\text { rock }\end{array}$ & Yes & Yes & 78.2 & Yes & Volcanic \\
\hline 2 & Ternate & Yes & Yes & Yes & $\begin{array}{l}\text { Dominated by } \\
\text { pyroclastic deposits, } \\
\text { lahars, lava, breccias } \\
\text { from Young, Adult, } \\
\text { and Old Gamalama }\end{array}$ & Yes & Yes & 73.0 & Yes & Volcanic \\
\hline 3 & Maitara & Yes & Yes & Yes & $\begin{array}{l}\text { Holocene volcanic } \\
\text { rock }\end{array}$ & Yes & Yes & 51.2 & Yes & Volcanic \\
\hline 4 & Tidore & Yes & Yes & Yes & $\begin{array}{l}\text { Dominated by } \\
\text { Holocene volcanic } \\
\text { rocks with alluvial } \\
\text { material on the west } \\
\text { and east coasts of the } \\
\text { island }\end{array}$ & Yes & Yes & 77.6 & Yes & Volcanic \\
\hline 5 & Mare & Yes & Yes & No & $\begin{array}{l}\text { Holocene volcanic } \\
\text { rock }\end{array}$ & No & Yes & 63.8 & Yes & $\begin{array}{l}\text { Non- } \\
\text { volcanic }\end{array}$ \\
\hline 6 & Moti & Yes & Yes & Yes & $\begin{array}{l}\text { Holocene volcanic } \\
\text { rock }\end{array}$ & Yes & Yes & 73.8 & Yes & Volcanic \\
\hline 7 & Makian & Yes & Yes & Yes & $\begin{array}{l}\text { Dominated by } \\
\text { Holocene volcanic } \\
\text { rock with Kayasa } \\
\text { formation (igneous } \\
\text { rock) on the east side } \\
\text { of the island }\end{array}$ & Yes & Yes & 83.0 & Yes & Volcanic \\
\hline 8 & $\begin{array}{l}\text { Moda- } \\
\text { yama }\end{array}$ & Yes & Yes & No & Uplifted coral reef & No & No & 0.0 & No & $\begin{array}{c}\text { Non- } \\
\text { volcanic }\end{array}$ \\
\hline
\end{tabular}


Continuation of Table 2. Small volcanic islands in North Maluku based on geomorphological aspects

\begin{tabular}{|c|c|c|c|c|c|c|c|c|c|c|}
\hline \multirow{3}{*}{$\mathrm{Nu}$} & \multirow{3}{*}{ Name } & \multicolumn{8}{|c|}{ Characteristics } & \multirow{3}{*}{$\begin{array}{l}\text { Conclu- } \\
\text { sion }\end{array}$} \\
\hline & & \multirow{2}{*}{$\begin{array}{c}\text { Area } \\
\leq 2,000 \\
\mathrm{~km}^{2}\end{array}$} & \multirow{2}{*}{$\begin{array}{l}\text { Near } \\
\text { subduc } \\
\text { tion } \\
\text { zone }\end{array}$} & \multirow{2}{*}{$\begin{array}{l}\text { Radial } \\
\text { river } \\
\text { flow } \\
\text { pattern }\end{array}$} & \multirow[t]{2}{*}{ Material } & \multirow{2}{*}{$\begin{array}{l}\text { There are active } \\
\text { \& inactive cones } \\
\text { /craters/calde- } \\
\text { ras/domes/ } \\
\text { maars }\end{array}$} & \multirow{2}{*}{$\begin{array}{l}\text { Steep } \\
\text { slope } \\
(>25 \%)\end{array}$} & \multicolumn{2}{|c|}{$\begin{array}{c}\text { Hilly and } \\
\text { mountainous } \\
\text { morphology }\end{array}$} & \\
\hline & & & & & & & & $\%$ & $\begin{array}{l}\text { Avail } \\
\text { able }\end{array}$ & \\
\hline 9 & Koyua & Yes & Yes & No & $\begin{array}{l}\text { Dominated by } \\
\text { uplifted coral reefs } \\
\text { and Holocene } \\
\text { volcanic rocks } \\
\text { (breccia and lava) } \\
\text { and alluvial material } \\
\text { on the east side of } \\
\text { the island }\end{array}$ & No & No & 29.4 & No & $\begin{array}{c}\text { Non- } \\
\text { volcanic }\end{array}$ \\
\hline 10 & $\begin{array}{l}\text { Waida- } \\
\text { bo }\end{array}$ & Yes & Yes & No & $\begin{array}{l}\text { Dominated by } \\
\text { uplifted coral reefs } \\
\text { with a little breccia } \\
\text { and lava rock on the } \\
\text { west side of the } \\
\text { island }\end{array}$ & No & No & 5.0 & No & $\begin{array}{c}\text { Non- } \\
\text { volcanic }\end{array}$ \\
\hline 11 & Gafi & Yes & Yes & No & $\begin{array}{l}\text { Volcanic rocks } \\
\text { consist of breccia } \\
\text { and lava, with } \\
\text { inserts of sandy tuff, } \\
\text { claystone, and } \\
\text { sandstone }\end{array}$ & No & Yes & 39.5 & Yes & $\begin{array}{c}\text { Non- } \\
\text { volcanic }\end{array}$ \\
\hline 12 & Siko & Yes & Yes & No & $\begin{array}{l}\text { Volcanic rocks } \\
\text { consist of breccia } \\
\text { and lava, with } \\
\text { inserts of sandy tuff, } \\
\text { claystone, and } \\
\text { sandstone }\end{array}$ & No & Yes & 54.3 & Yes & $\begin{array}{c}\text { Non- } \\
\text { volcanic }\end{array}$ \\
\hline 13 & Talimau & Yes & Yes & No & $\begin{array}{l}\text { Volcanic rocks } \\
\text { consist of breccia } \\
\text { and lava, with } \\
\text { inserts of sandy tuff, } \\
\text { claystone, and } \\
\text { sandstone }\end{array}$ & No & No & 7.0 & No & $\begin{array}{c}\text { Non- } \\
\text { volcanic }\end{array}$ \\
\hline 14 & Tameti & Yes & Yes & No & $\begin{array}{l}\text { Combination of } \\
\text { limestone and } \\
\text { volcanic rock } \\
\text { consisting of breccia } \\
\text { and lava, with the } \\
\text { insertion of sandy } \\
\text { tuff, claystone, and } \\
\text { sandstone }\end{array}$ & No & No & 0.0 & No & $\begin{array}{c}\text { Non- } \\
\text { volcanic }\end{array}$ \\
\hline 15 & Tawale & Yes & Yes & No & Limestone & No & Yes & 0.0 & No & $\begin{array}{c}\text { Non- } \\
\text { volcanic }\end{array}$ \\
\hline 16 & Muari & Yes & Yes & No & $\begin{array}{l}\text { The north side of the } \\
\text { island is limestone, } \\
\text { the south side is } \\
\text { volcanic rocks } \\
\text { consisting of breccia } \\
\text { and lava, with the } \\
\text { insertion of sandy } \\
\text { tuff, claystone, and } \\
\text { sandstone }\end{array}$ & No & Yes & 0.0 & No & $\begin{array}{c}\text { Non- } \\
\text { volcanic }\end{array}$ \\
\hline 17 & Latalata & Yes & Yes & No & $\begin{array}{l}\text { Volcanic rocks } \\
\text { consist of breccia } \\
\text { and lava, with } \\
\text { inserts of sandy tuff, } \\
\text { claystone, and } \\
\text { sandstone }\end{array}$ & No & Yes & 0.0 & No & $\begin{array}{c}\text { Non- } \\
\text { volcanic }\end{array}$ \\
\hline
\end{tabular}

Source: Research Analysis, 2020 


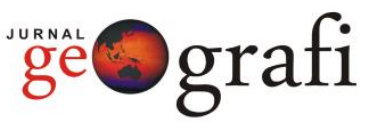

\section{CONCLUSION}

Geomorphological

aspects consisting of morphology, morphogenesis, morphochronology, and morphoarrangement, can be used as an approach in identifying small volcanic islands in North Maluku Province. The parameters that can be used in the identification of small volcanic islands include island area, material type, location and morphoarrangement, type of river flow patterns, and landform features which include the presence of landforms from volcanic processes (morphochronology), slopes, and morphology.

Based on the spatial analysis using the 5 previously mentioned parameters, information can be obtained that there are at least 6 of the 17 small islands in North Maluku that meet the criteria to be referred to as small volcanic islands, namely Hiri Island, Ternate, Maitara, Tidore, Moti, and Makian. The data on small volcanic islands and their characteristics can be used and developed as data in disaster management efforts, especially those related to volcanoes in North Maluku Province.

\section{ACKNOWLEDGMENTS}

The authors thanks to the Indonesian Ministry of Research, Technology, and Higher Education for the PTUPT research scheme 2020 - PADEPOKAND. The author dedicates this article to Prof. Sunarto and Prof. Hartono, who passed away in 2020. Finally, the author would like to thank the reviewers for their constructive comments and suggestions to improve this article.

\section{REFERENCES LIST}

Chan, H.P., Chang, C.P., Lin, T.H., Blackett, M., Kuo-Chen, H., \& Lin A.T.S. (2020). The potential of satellite remote sensing for monitoring the onset of volcanic activity on Taipei's doorstep, International Journal of Remote Sensing, 41:4, 1372-1388.

Coello-Bravo, J.J., Márquez, Á., Herrera, R., Huertas, M.J., Ancochea, E. (2020). Multiple related flank collapses on volcanic oceanic islands: Evidence from the debris avalanche deposits in the Orotava Valley water galleries (Tenerife, Canary Islands), Journal of Volcanology and Geothermal Research, 401, 106980.

De Belizal, E., Lavigne, F., Hadmoko, D.S., Degeai, J.P., Dipayana, G.A., Mutaqin, B.W., Marfai, M.A., Coquet, M., Le Mauff, B., Robin, A.K., Vidal, C., Cholik, N., Nurnaning, A. (2013). RainTriggered Lahars Following The 2010 Eruption Of Merapi Volcano, Indonesia: A Major Risk, Journal of Volcanology and Geothermal Research, 261, 330-347.

Gogarten, E. (1918). Die Vulkane der nördlichen Molukken. De Gruyter.

Hadmoko, D.S., De Belizal, E., Mutaqin, B.W., Dipayana, G.A., Marfai, M.A., Lavigne, F., Sartohadi, J., Worosuprojo, S., Starheim, C.C.A., Gomez, C. (2018). Post-Eruptive Lahars at Kali Putih Following the 2010 Eruption of Merapi Volcano, Indonesia: Occurrences and Impacts, Natural Hazards 94(1), pp. 419444.

Hall, R. \& Wilson, M.E.J. (2000). Neogene sutures in eastern Indonesia. Journal of Asian Earth Sciences, 18(6), 781-808.

Hidayat, A., Marfai, M.A., Hadmoko, D.S. (2019). Pemetaan Pulau Vulkanik Kecil di Indonesia: Studi Pendahuluan untuk Manajemen Bencana Erupsinya. Jurnal Planoearth 4(2). p.95-101.

Hidayat, A., Marfai, M.A., Hadmoko, D.S. (2020). Eruption Hazard And Challenges of Volcanic Crisis Management On A Small Island: A Case Study on Ternate Island-Indonesia. International Journal of Geomate 18(66). p.171-178.

Kervyn, M., Kervyn, F., Goossens, R., Rowland, S.K., Ernst, G.G.J. (2007). Mapping volcanic terrain using highresolution and $3 D$ satellite remote sensing. Geological Society, London, Special Publications, 283, 5-30, 1 January 2007.

Lavigne, F., Thouret, J.-C., Voight, B., Suwa, H., Sumaryono, A. (2000). Lahars at Merapi volcano: an overview. Journal of Volcanology and Geothermal Research, 100: 423-456.

MAGMA Indonesia, 2020. https://magma.vsi.esdm.go.id/ [8 Desember 2020]. 
Mei, E.T.W., Lavigne, F., Picquot, A., De Belizal, E., Brunstein, D., Grancher, D., Sartohadi, J., ChoelikNoer., dan Vidal, C. (2013). Lessons learned from the 2010 evacuations at Merapi volcano, Journal of Volcanology and Geothermal Research.

Mutaqin, B.W., Lavigne, F., Hadmoko, D.S., Malawani, M.N. (2019a). Volcanic Eruption-Induced Tsunami in Indonesia: A Review, IOP Conf. Ser.: Earth Environ. Sci. 256012023.

Mutaqin, B.W., Lavigne, F., Sudrajat, Y., Handayani, L., Lahitte, P., Virmoux, C., Hiden, Hadmoko, D.S., Komorowski, J.C., Hananto, N., Wassmer, P., Hartono, Boillot-Airaksinen, K. (2019b). Landscape evolution on the eastern part of Lombok (Indonesia) related to the $1257 \mathrm{CE}$ eruption of the Samalas Volcano, Geomorphology 327, pp. 338-350.

Mutaqin, B.W. \& Lavigne, F. (2019). Oldest Description of a Caldera-forming Eruption in Southeast Asia Unveiled in Forgotten Written Sources, GeoJournal.

Napieralski, J., Barr, I., Kamp, U., Kervyn, M. (2013). Remote sensing and GIScience in geomorphological mapping. In: Shroder, J. (Editor in Chief), Bishop, M.P. (Ed.), Treatise on Geomorphology. Academic Press, San Diego, CA, vol. 3, Remote Sensing and GIScience in Geomorphology, pp. 187-227.

Rampengan, M.M.F., Boedhihartono, A.L., Margules, C., Sayer, J., Law, I., Gaillard, J.-C.,Tien, O.T.N., Linh, T.T.M. (2016). Agroforestry on an Active Volcanic Small Island in Indonesia: Prospering with Adversity. Geographical Research 54(1):19-34.

RI (Republik Indonesia). (2007). UndangUndang No. 27 Tahun 2007 Tentang Pengelolaan Wilayah Pesisir dan Pulau-Pulau Kecil. Sekretariat Negara. Jakarta.

Santamarta, J.C., Lario-Bascones, R.J., Rodríguez-Martín, J., HernándezGutiérrez, L.E., Poncela, R. (2014). Introduction to Hydrology of Volcanic Islands, IERI Procedia, 9, 135-140.

Stokes, M., \& Gomes, A. (2020). Alluvial fans on volcanic islands: A morphometric perspective (São Vicente, Cape Verde), Geomorphology, 368, 107356.

Syiko, S.F., Ayu, T.R., Yudono. (2013). Evacuation route planning in Mount Gamalama, Ternate Island, Indonesia. The 3rd International Conference on Sustainable Future for Human Security SUSTAIN 2013. Procedia Environmental Sciences 17, 344-353.

Thouret, J.C., Abdurachman, K.E., Bourdier, J.L. and Bronto, S. (1998). Origin, Characteristics, and Behaviour of Lahars following the 1990 Eruption of Kelud Volcano, Eastern Java. Indonesia. Bulletin of Volcanology, 59(7), 460-480.

Thouret, J.-C. (1999). Volcanic geomorphology-an overview, EarthScience Reviews, 47(1-2), 95-131.

Thouret, J.C., Lube, G., Liew, S.C., Cronin, S.J., Surono. (2010). Analysis of the 2006 eruption deposits of Merapi Volcano, Java, Indonesia, using high-resolution IKONOS images and complementary ground based observations. Remote Sensing of Environment 114, 1949-1967.

United Nations Convention on the Law of the Sea (UNCLOS). (1982). Montego Bay (Jamaica).

Velmurugan, A. (2008). Chapter 1 - The Nature and Characters of Tropical Islands, Editor(s): C. Sivaperuman, A. Velmurugan, A.K. Singh, I. Jaisankar, Biodiversity and Climate Change Adaptation in Tropical Islands, Academic Press, 3-30.

Wilkinson, E., Lovell, E., Carby, B., Barclay, J., Robertson, R.E. (2016). The Dilemmas of Risk-Sensitive Development on a Small Volcanic Island. Resources, 5(2), 21. 